\title{
0 que de inesperado a vida nos reserva
}

\section{João Carneiro}

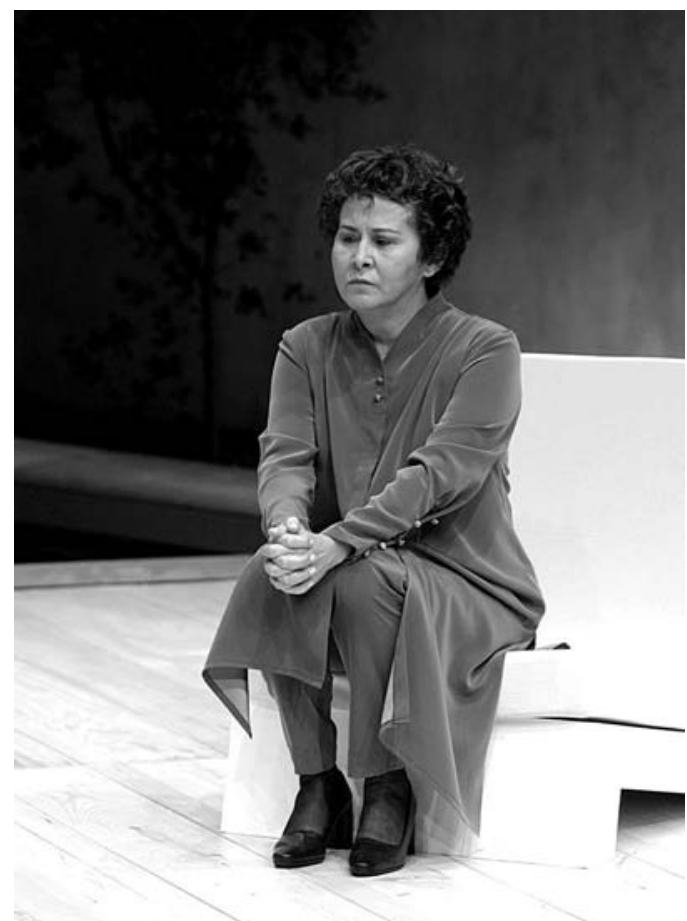

Em A Cabra, ou quem é Silvia?, de Edward Albee, o título sugere uma complicação: se aceitarmos, ou se quisermos, que Silvia refere também Os dois cavalheiros de Verona, de Shakespeare, Silvia refere ainda uma das personagens centrais da peça, aquela por quem dois amigos se apaixonam, o que fará com que um traia o outro, o que faz com que uma história de amor e de amizades se transforme numa história de traições e de bandidos, o que fará do final da peça de Shakespeare um final inesperado, o que fez que muito bons críticos, à luz desse final, desconsiderassem razoavelmente a peça.

$E$, no entanto, Sílvia é aquela por quem o inesperado acontece, aquela por quem o amor chega aos homens. Silvia, sem querer, vem perturbar o equilibrio entre a emoção e a razão, e Silvia é só uma mulher. Numa outra peça de Shakespeare, uma rainha apaixona-se por um burro, na sequência de uma história de ciúmes, de vingança e de um encantamento que pesa, temporariamente, sobre a rainha e sobre o burro, que antes era homem e depois volta a ser homem - altura em que a paixão da rainha deixa, também, de existir. Em qualquer dos casos, o amor, o desejo e o ciúme perturbam a vida de homens e mulheres, e não é por algumas destas personagens pertencerem à esfera do sobrenatural que escapam a aventuras complicadas.

Albee, na sua peça, transformou Silvia numa cabra

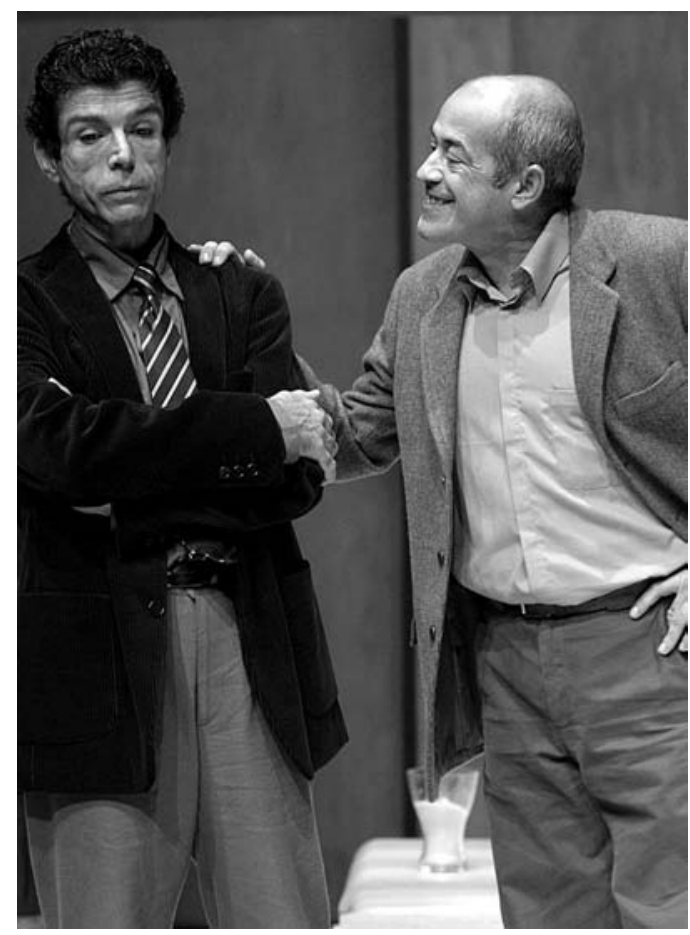

A cabra, ou quem éSilvia? de Edward Albee, enc. Álvaro Correia, Teatro da Comuna, 2005 (Cucha Carvalheiro), fot. Susana Paiva.

A cabra, ou quem é Silvia? de Edward Albee, enc. Álvaro Correia, Teatro da Comuna, 2005 (Carlos Paulo e Victor Soares), fot. Susana Paiva.

e fez dela aquela por quem a infelicidade entra na família dos homens, porque Martin, um arquitecto famoso, se apaixona por ela. A sua mulher não gosta de saber que há uma outra, mas tudo se altera radicalmente quando se sabe que a outra é um bicho. A mulher, o amigo, o filho de Martin, todos são apanhados nas malhas da surpresa total, e todos reagem de maneiras diferentes, é verdade. Penso que o melhor que a peça de Albee pode fazer é mostrar-nos que não sabemos nem o que é a paixão, nem o que é o desejo, nem o que podem ser os causadores destes sentimentos, muito menos ainda quais serão as nossas reacções perante as surpresas que, de cada vez, a vida nos apresenta.

0 espectáculo da Comuna, na encenação de Álvaro Correia, com as exemplares interpretações de Carlos Paulo, Cucha Carvalheiro, João Tempera e Victor Soares teve a extraordinária virtude de nos fazer ficar estupefactos perante toda esta história, perante todas estas situações, e perante todas estas personagens. Soube recriar, a partir do texto original, os sentimentos de admiração, de espanto e de medo que podemos sentir perante o que de inesperado a vida nos reserva, e para o qual não há resposta preparada. Tudo o que podemos fazer é saber que não estamos livres de nada. É uma lição antiga, que muito, mas muito raramente nos é contada de maneira tão exemplar. 